\title{
RELACJA CZYNNOS̄C̄-WYTWŌR A PRZEDMIOT TEORII POZNANIA
}

1. Znana rozprawa K. Twardowskiego o czynnościach i wytworach nie dopowiedziała pewnych spraw do końca. Chcę tu poruszyć jedną $\mathrm{z}$ nich, związaną $\mathrm{z}$ pojmowaniem poznania jako przedmiotu teorii poznania.

Rozróżniam dwie zasadnicze koncepcje teorii poznania,. koncepcje nieredukowalne, prowadzące do komplementarnych ujęć poznania i sprawy jego wartości. Według pierwszej poznanie jest składnikiem otaczającej nas rzeczywistości, jest w nią uwikłane rozmaitymi związkami, zwłaszcza przyczynowymi. Własność i wartość tak ujętego poznania bada się $\mathrm{w}$ perspektywie tych przedmiotowych, przyczynowych uwikłań i uwarunkowań. Taka teoria poznania ma charakter bądź scjentystyczny, bądź metafizykalny, jest teorią zależną od jakiejś ogólniejszej teorii rzeczywistości.

Według drugiej koncepcji poznanie jest daną, pojawiającą się w polu świadomości jako pewna sensowna całość, która spełnia rolę (lub pretenduje do spełniania roli) informatora o czymś. Tak pojęte poznanie informator nie jest składnikiem rzeczywistości, członem związku przyczynowego, a w stosunku do innych poznań - informatorów (ze względu na swój sens i sposób wystąpienia w świadomości) pozostaje w relacjach zgodności lub niezgodności, potwierdzania lub obalania, wynikania, uzupełnienia itp. Zwolennicy tej koncepcji teorii poznania uważają, iż jedynie na jej terenie uzyskujemy samoświadomość charakteru i wartości poznania w sposób niedogmatyczny, unikając błędu ,petitio principii".

Niektórzy jednak sądzą, że nie da się poprawnie rozważyć w ramach jednej dyscypliny naukowej zarówno poznania jako czynności jak i poznania jako wytworu: pierwsze bowiem ma charakter realnego procesu, drugie zaś - zwłaszcza w swej językowo ukształtowanej postaci - ma charakter przedmiotu czysto intencjonalnego.

2. Jeżeli poprzez czynność poznawania rozumiemy realny proces lub zdarzenie rozgrywające się $\mathrm{w}$ ramach strumienia świadomości określo- 
nego przedmiotu poznającego, to przez wytwór tej czynności można rozumieć: 1) immanentny składnik tej czynności, jej treść równie realną jak sama czynność ( $\mathrm{w}$ tym sensie wytwờrem aktu spostrzegania jest treść tego aktu), 2) skutek tej czynności w jej podmiocie w postaci bądź a) stanu świadomości (w tym sensie wytworem aktu spostrzegania jest poznawcze uchwycenie, widzenie przedmiotu spostrzeżenia), bądź b) dyspozycji (a więc możności np. ponowienia tego widzenia albo wtórnego uobecnienia sobie w przypomnieniu lub wyobrażeniu tego, có niegdyś było spostrzeżone), 3) rezultat poznawczy czynności, bądź jako a) zawartość intencjonalnego korelatu aktu (przedmiot intencjonalny lub noemat), bądź jako b) znaczenie językowego sformułowania (wypowiedzenia) treści aktu lub zawartości intencjonalnego korelatu aktu (wyrażenie językowe odpowiedniej kategorii). Tak określone rezultaty mają te czynności, które zawierają intencjonalne odniesienie do czegoś. Z tym, iż wytwór w sensie $3 \mathrm{a}$ w swej normalnej postaci występuje w trakcie poznawania i uzyskiwania informacji, a także podczas przeżywania sta$\mathrm{nu} \mathrm{np}$. widzenlia czegoś jako poznawczy środek przezroczysty (medium quo lub in quo) a nie jako przedmiot (temat) naszych świadomych czynności. I wreszcie jedna uwaga: nie należy $\mathrm{z}$ tego względu, że $3 \mathrm{~b}$ jako rezultat czynności np. spostrzegania jest zarazem wytworem określonej czynności językotwórczej (np. czynności kształtowania, konstruowania zdania spostrzeżeniowego) utożsamiać lub mieszać te obie czynności, aczkolwiek one zazwyczaj idą w parze i mogą niejako zlewać się w jedną całość przeżyciową.

Tak czy owak, wytwór - również wtedy, gdy stanowi całość różną czynności, której jest wytworem - jest zawsze $1^{\circ}$ pochodny w stosun$\mathrm{ku}$ do czynności, $2^{\circ} \mathrm{w}$ swej funkcji poznawczej zależny od określonej czynności; zależność ta nie polega na tym, że np. prawdziwość (do której pretenduje poznanie - wytwór) jest także cechą fundującej go czynności (gdyż prawdziwość w sensie ścisłym nie jest kwalifikacją czynności), lecz na tym, iż pretensja poznawcza wytworu - np. widzenia czegoś lub sądu spostrzeżeniowego, stanowiącego intelektualną formułę tego, co widzimy lub tego, że widzimy coś - konstytuuje się i uprawomocnia $\mathrm{w}$ swej pewności $\mathrm{w}$ przebiegu czynności poznawania ( $\mathrm{w}$ spostrzeganiu czegoś) i w związku z przebiegiem tej czynności. Dlatego problematyki wartości (uprawomocnienia) rezultatów poznawczych nie można oderwać od problematyki ich związku z czynnościami poznawczymi, z problematyką charakteru tych czynności. Informatywność, prawdziwościowość naszych poznań jest nieprzypadkowo powiązana z ich „rezultatywnością”; poznania osiągamy dzięki czynnościom świadomego kontaktowania się z przedmiotami. Wiszelkie zabiegi uzasadniania jakiegoś rezultatu poznawczego ostatecznie odwołują się do występo- 
wania określonej relacji między tym rezultatem a odpowiednią czynnością poznawczą.

3. Relację poznawanie - rezultat poznawczy można ujmować rozmaicie. Zależnie od sposobu ujęcia będziemy mieli do czynienia z psychologią lub psychofizjologią poznania, z socjologią poznania, z metafizyką poznania. Można też nadać tej relacji charakter stosunku cybernetycznego. Obok tych ujęć istnieje ujęcie w ramach właściwej (autonomicznej) teorii poznania. W tym ujęciu nie znika nam czynność jako człon relacji poznawczej, lecz nabiera ona nowego znaczenia, jako miejsce" i ,droga" rodzenia się (konstytuowania) sensu poznawczego i pretensji poznawczej jej wytworów.

\section{RELATION TÄTIGKEIT-ERGEBNIS UND DER GEGENSTAND DER ERKENNTNISTHEORIE}

$\mathrm{Zusammenfassung}$

Der Verfasser erwägt verschiedene Bedeutungen des „Terminus” Ergebnis und die enge Verbindung zwischen der Erkenntnistätigkeit und ihrem Ergebnis. Erkenntnis als Ergebnis hat ihre Begründung und Berechtigung im Erkennen als Tätigkeit. Konsequent muss richtig begriffene Erkenntnistheorie sowohl mit den Erkenntnistätigkeiten, als auch mit ihren Ergebnissen sich befassen. 